\begin{tabular}{|l|l|l||}
\hline \multicolumn{2}{|c|}{ PublisherInfo } \\
\hline \hline PublisherName & $:$ & BioMed Central \\
\hline \hline PublisherLocation & $:$ & London \\
\hline \hline PublisherImprintName & $:$ & BioMed Central \\
\hline \hline
\end{tabular}

\title{
Outcomes after long-term acute care
}

\begin{tabular}{|l|l|l||}
\hline \multicolumn{2}{|c|}{ ArticleInfo } \\
\hline \hline ArticleID & $:$ & 4132 \\
\hline \hline ArticleDOI & $:$ & $10.1186 /$ ccf-1999-702 \\
\hline \hline ArticleCitationID & $:$ & 702 \\
\hline \hline ArticleSequenceNumber & $:$ & 69 \\
\hline \hline ArticleCategory & $:$ & Paper Report \\
\hline \hline ArticleFirstPage & $:$ & 1 \\
\hline \hline ArticleLastPage & $:$ & 3 \\
\hline \hline & & RegistrationDate : 1999-7-6 \\
ArticleHistory & $:$ & OnlineDate $1999-7-6$ \\
\hline \hline ArticleCopyright & $:$ & Current Science Ltd1999 \\
\hline \hline ArticleGrants & $:$ & \\
\hline \hline ArticleContext & $:$ & 130541111 \\
\hline \hline
\end{tabular}




\section{Keywords}

Long term critical care, morbidity, mortality

\section{Comments}

Despite not being statistically powerful and with some methodological deficencies, this paper is a useful and sobering reminder that older patients with co-morbid disease have a very high mortality following critical illness, unless they make a quick recovery (within a few days). This adds weight to the arguments that treatment should always be individualised, but continuing organ supportive therapies in older patients with co-morbid disease, is not morally or financially justifiable at the current time.

\section{Introduction}

Since the early 1980s, long-term acute-care (LTAC) hospital facilities have been created in the USA, to deal with the small percentage (3-6\%) of patients who require prolonged organ supportive therapies, most commonly, mechanical ventilation. These patients undergo prolonged hospitalization at a considerable personal and financial cost. To date there has been very limited outcome data for such patients, and no attempt to identify predictors of outcome.

\section{Aims}

To prospectively evaluate the morbidity and mortality of chronically critically ill patients, and to determine any predictive factors that correlate with outcome.

\section{Methods}

A total of 133 consecutive patients were followed for one year. Eligible cases were those who had been ventilated for more than 14 days in acute care hospital intensive care units (ICUs). Any patients 
who had been chronically ventilated prior to this acute admission were excluded. Demographic data, history of current illness, nature and severity of co-morbidities and performance status prior to admission were recorded. The acute physiology and chronic health evaluation (APACHE II) score was calculated over the first $24 \mathrm{~h}$ of LTAC admission. Outcome at one year was established by interview, as appropriate, for each case.

\section{Results}

For the 133 patients studied, average age was $71 \pm 12$ years $(77 \%>65$ years $)$ and $52 \%$ were female. The average APACHE II score was $23 \pm 6$, average number of co-morbidities was $3.2 \pm 1.6$, and the median number of ICU days prior to transfer was 25 . Ninety five percent of patients had a medical diagnosis precipitating ICU admission, however $18 \%$ of these patients had required a major surgical procedure during their acute illness. Mean length of stay in the LTAC hospital was $63 \pm 50$ days. Sixtysix $(50 \%)$ of the study patients died whilst in the LTAC hospital. Of the surviving 67 patients, only 30 were alive at one year, and of these, only 11 were oriented, ambulatory and independent. The best predictors of outcome were age and independence prior to admission. Patients over 75, or those over 65 with impared function prior to admission, had a $95 \%$ mortality at one year. This group spent $71 \%$ of their time in the LTAC hospital, and only $7 \%$ in their homes.

\section{Discussion}

These results are comparable to previous outcome studies in ICU patients requiring prolonged mechanical ventilation. Direct comparison with other LTAC hospitals is difficult due to the heterogenity of admission policies, and hence, the case mix. The fact that only $8 \%$ of patients admitted to this LTAC were alive and independent at one year is a matter of great concern. These patients and their families undergo a great deal of suffering, for arguably no benefit in the vast majority of cases. This study is limited due to its size, but does at least give some useful indicators, which need to be more thoroughly addressed in larger, multi-center studies.

\section{References}

1. Carson SS, Bach PB, Brzozowski L, Leff A: Outcomes after long-term acute care. Am J Respir Crit Care Med. 1999, 159: 1568-1573. 